\title{
Characterization of Isolates of Phytophthora infestans from Tomato and Potato in North Carolina from 1993 to 1995
}

\author{
Dawn E. Fraser, Paul B. Shoemaker, and Jean B. Ristaino, Department of Plant Pathology, North Carolina State \\ University, Raleigh
}

\begin{abstract}
Fraser, D. E., Shoemaker, P. B., and Ristaino, J. B. 1999. Characterization of isolates of Phytophthora infestans from tomato and potato in North Carolina from 1993 to 1995. Plant Dis. 83: 633-638.

Eighty-five isolates of Phytophthora infestans from 33 tomato and 8 potato fields in North Carolina, South Carolina, and Tennessee were collected from 1993 to 1995 and tested for mating type, sensitivity to metalaxyl, and allozyme genotype at glucose-6-phosphate isomerase (Gpi) and peptidase (Pep) loci. One isolate collected from potato in eastern North Carolina in 1994 was the A1 mating type, whereas all other isolates from potato and tomato were the A2 mating type. Six isolates were sensitive to metalaxyl $(<40 \%$ growth at $1.0 \mu \mathrm{g}$ of metalaxyl per ml), nineteen isolates were intermediate in sensitivity to metalaxyl ( $>40 \%$ growth at $1.0 \mu \mathrm{g}$ of metalaxyl per $\mathrm{ml}$ and $<40 \%$ growth at $100 \mu \mathrm{g}$ of metalaxyl per $\mathrm{ml}$ ), and sixty isolates were resistant to metalaxyl (>40\% growth at 1.0 and $100 \mu \mathrm{g}$ of metalaxyl per $\mathrm{ml}$ ). Four different allozyme genotypes at the Gpi and Pep loci were identified. The single A1 isolate found on potato in eastern North Carolina had the dilocus allozyme genotype Gpi 86/100, Pep 92/100 and was identified as the US-1 genotype. Fifty-five isolates had the dilocus allozyme genotype Gpi 100/111, Pep 100/100 and were classified as the US-7 genotype, whereas twenty-four isolates were Gpi 100/111/122, Pep 100/100 and were classified as the US-8 genotype. Two isolates that were sensitive to metalaxyl and seventeen isolates that were intermediate in sensitivity to metalaxyl were found among the US-7 and US-8 genotypes. In addition, five isolates had the allozyme genotype Gpi 100/100, Pep 92/100 (similar to the previously reported US-6 genotype), but they were the A2 mating type and either sensitive or intermediate in response to metalaxyl. These isolates composed a new genotype not previously reported in the United States and were designated as US-18. The US-7 genotype was more frequent on tomato in western North Carolina and the US- 8 genotype was present on potato in eastern North Carolina, indicating that different inoculum sources are responsible for epidemics on the two crops in different regions of the state.
\end{abstract}

Late blight, caused by the heterothallic oomycete fungus Phytophthora infestans (Mont.) de Bary, has historically been an important disease of potatoes and tomatoes (31). In recent years, the frequency and severity of epidemics in potato and tomato crops worldwide have increased (13). The increase of disease and associated yield losses has coincided with changes in populations of $P$. infestans, metalaxyl resistance, and migrations of new genotypes of the pathogen from Mexico (15).

Both A1 and A2 mating types of $P$. infestans occur in Mexico, the center of diversity of the fungus $(13,15,30)$. The A1 mating type was found worldwide in all populations of the late blight pathogen outside of Mexico prior to 1984 (7,13,34). A change in population of $P$. infestans was detected in 1984, when isolates with the A2 mating type were found in Europe and

Corresponding author: J. B. Ristaino

E-mail: Jean_Ristaino@ncsu.edu

Accepted for publication 19 March 1999.

Publication no. D-1999-0426-03R

(C) 1999 The American Phytopathological Society subsequently worldwide $(7,8,11,22,24,26$, $29,34,36,41)$. These new isolates had different allozyme alleles at the glucose-6phosphate isomerase (Gpi) and peptidase (Pep) loci than did the US-1 clonal lineage found previously, and they were more aggressive $(16,20)$.

A number of distinct clonal lineages have been reported in populations of $P$. infestans $(19,20)$. Phenotypic markers including mating type, specific virulence, and metalaxyl sensitivity have been used to characterize populations of $P$. infestans $(13,14,19,24,34$, 42,43). Goodwin et al. (17) developed a moderately repetitive nuclear DNA probe (RG57) that provided a useful tool for fingerprinting genotypes by restriction fragment length polymorphisms (RFLP). New genotypes of $P$. infestans have been reported as a result of recent migrations from Mexico $(15,21,28,37,39)$. These new genotypes have replaced the older genotypes in the United States, Europe, and elsewhere (19). The potential for oospore formation and enhanced survival of the pathogen may occur if both A1 and A2 mating types are found on plants in the same field, since sexual reproduction may occur $(3,4,7,10)$. Evidence of sexual reproduction in $P$. infestans populations has been provided through identification of recombinant genotypes, characterization of populations existing in Hardy-Weinberg equilibrium, co-occurrence of A1 and A2 mating types, and direct observations and polymerase chain reaction (PCR) of oospores in plant tissue $(3,10,20,32,40)$. Homothallic production of oospores can also occur in $P$. infestans in response to many commonly used fungicides and may have widespread implications for disease management $(2,44)$.

Resistance to the fungicide metalaxyl in these new genotypes of $P$. infestans has played a major role in the increased severity of the late blight epidemics observed in recent years $(8,9,27,33)$. Metalaxyl was first used for control of late blight in Europe in the late 1970s, but within two to three seasons of use, isolates of $P$. infestans resistant to metalaxyl appeared in European populations $(5,9)$. Metalaxyl-resistant populations of $P$. infestans have increased in the United States since 1991 and occur widely $(6,8,21)$.

Late blight epidemics in tomato production areas of North Carolina, South Carolina, and Tennessee were sporadic before 1991 (35). In 1991, the disease was widespread, especially in the western part of North Carolina where fresh market tomatoes are grown. The disease has occurred in that area in each growing season between 1991 and 1998. In potato production areas in the eastern coastal region of North Carolina, outbreaks of late blight have been increasing in severity, and severe losses occurred in some grower fields in 1994, 1995, 1997, and 1998.

Efforts are underway to develop genetic resistance to the disease on both tomato and potato in North Carolina. Characterization of genetic variation in pathogen populations within North Carolina will assist breeding efforts and improve fungicide management regimes. The objective of this study was to characterize isolates of $P$. infestans from many different tomato and potato production fields in North Carolina and from neighboring counties in South Carolina and Tennessee, using phenotypic and genotypic markers. The influence of prior fungicide use in the field on the characteristics observed was also examined.

\section{MATERIALS AND METHODS}

Isolate collection. Eighty-five isolates of $P$. infestans were collected between 1993 and 1995. Seventy-three isolates were collected from tomato fields and twelve isolates were collected from potato fields (Ta- 
ble 1). Most isolates were collected from tomato fields in North Carolina in 1994; however, five isolates were collected in coastal South Carolina and two isolates were collected from a single tomato field in eastern Tennessee in 1994 (Fig. 1). Most of the eight potato production fields sampled were located in eastern North Carolina, while the thirty-three tomato production fields were located in western North Carolina. Some of the tomato and potato fields sampled included unsprayed home gardens in western North Carolina. Sampling strategies were designed to sample as many individual fields as possible. Fifty-nine of the isolates represented single collections from different fields, and the remaining twenty-six isolates came from eight fields where multiple samples were taken. Most samples were collected early in the epidemics before the Most of the isolates collected were from tomato fields in 1994, since epidemics were more common on tomato than on potato during the time period of this particular study from 1993 to 1995 .

$P$. infestans was isolated from sporulating lesions by touching the lesion with a small piece of Rye-B agar placed on the tip of a scalpel (1). The piece of agar was transferred to a culture dish containing Rye-B agar. Cultures were then incubated at $18^{\circ} \mathrm{C}$ for 4 days, and the resulting colonies were transferred onto fresh Rye-B agar. When lesions with sporangia were not visible or when tissue was severely blighted, a small piece of infected tissue was placed in a sterile petri dish and the tissue was covered by a thin slice of potato tuber previously plants became heavily diseased and necrotic.

surface-disinfested in $10 \%$ sodium hypochlorite for $2 \mathrm{~min}$. These petri dishes were incubated at $18^{\circ} \mathrm{C}$ until $P$. infestans grew through the tuber slice and sporulated ( 3 to 5 days). Sporangia were removed with a transfer needle and placed on fresh Rye-B agar. Isolates were obtained by transferring hyphal tips from colony edges after 7 to 10 days. Isolates were maintained in pure culture in the dark on Rye-A or Rye-B agar in petri dishes or on Rye-B agar slant tubes at $18^{\circ} \mathrm{C}$.

Mating types and fungicide sensitivity of isolates. The mating type of each isolate was determined by cutting a 5-mm agar disk from the edge of a 2- to 3-week-old colony of $P$. infestans and placing it in the center of a petri dish containing Rye-B agar. One 5-mm disk of a known $\mathrm{A} 1$ and $\mathrm{A} 2$ isolate (isolate Bin16 [US-6] and isolate BG8 [US-7] obtained from W. Fry, Cornell University) was placed on the agar surface on either side of the center disk of the unknown isolate. Isolates that produced oospores with the known A1 tester isolate were the A2 mating type, and isolates that produced oospores with the known A2 tester isolate were the A1 mating type. In each test, the absence of oospores at the interface between colonies of the same mating type was used as a negative control. Positive controls included a cross between known opposite mating types. In no case were oospores produced in crosses with both tester isolates.

Each isolate was tested for sensitivity to the fungicide metalaxyl. Agar disks $(5 \mathrm{~mm})$ of each isolate were removed from the edge of an actively growing colony of $P$.

Table 1. Numbers of isolates of Phytophthora infestans collected from tomato and potato fields in North Carolina, South Carolina, and Tennessee from 1993 to 1995

\begin{tabular}{lrccccc}
\hline & \multicolumn{3}{c}{ Tomato } & & \multicolumn{3}{c}{ Potato } \\
\cline { 2 - 4 } \cline { 6 - 7 } Year & NC $^{\mathbf{a}}$ & SC & TN & & NC & Total \\
\hline 1993 & 5 & 0 & 0 & & 0 & 5 \\
1994 & 57 & 5 & 2 & & 9 & 73 \\
1995 & 4 & 0 & 0 & & 3 & 7 \\
Total & 66 & 5 & 2 & & 12 & 85 \\
\hline
\end{tabular}

${ }^{\mathrm{a}} \mathrm{NC}=$ North Carolina, $\mathrm{SC}=$ South Carolina, and $\mathrm{TN}=$ Tennessee.



Fig. 1. Map of North Carolina counties where isolates of Phytophthora infestans were collected from potato and tomato from 1993 to 1995 . Most of the potato production fields are in eastern North Carolina, whereas tomato production fields are in western North Carolina. infestans and placed at the center of a petri dish containing Rye-B agar amended with metalaxyl (Ridomil 2E; Novartis Seeds, Greensboro, NC) at concentrations of 0 , $0.1,1.0,10,100$, and $1,000 \mu \mathrm{g} \mathrm{ml}^{-1}$. There were four replicate dishes per isolate per concentration of metalaxyl. Controls consisted of Rye-B agar containing no metalaxyl. Control plates were incubated separately from fungicide-amended plates in a large growth chamber. Plates were incubated at $18^{\circ} \mathrm{C}$ in $12 \mathrm{~h}$ of alternating light and darkness for 14 to 21 days, when the colony in the absence of metalaxyl exceeded $3 \mathrm{~cm}$ but had not grown to reach the edges of the petri dish. Colony growth was evaluated by taking two perpendicular diameter measurements per colony. Isolate growth at each metalaxyl concentration was calculated as a percentage of the growth of the same isolate in the absence of metalaxyl. Subsets of the isolates were further tested using a floating leaf disk assay in a subsequent study (21). Tomato leaf disks were floated on solutions of metalaxyl containing concentrations of 0,5 , and $100 \mu \mathrm{g}$ of fungicide per $\mathrm{ml}$. Isolates that caused lesions at 5 and $100 \mu \mathrm{g}$ of metalaxyl per $\mathrm{ml}$ were considered resistant to the fungicide. Sensitivity to the fungicide was consistent between the agar and the leaf disk tests. Data from the agar assay are presented.

Isolates were grouped into three sensitivity categories. Isolates rated as sensitive had growth less than $40 \%$ of the nonamended control at 1.0 and $100 \mu \mathrm{g} \mathrm{ml}^{-1}$. Isolates rated as intermediate had growth greater than $40 \%$ of the nonamended control at $1.0 \mu \mathrm{g} \mathrm{ml}^{-1}$, but less than $40 \%$ of the nonamended control at $100 \mu \mathrm{g} \mathrm{ml} \mathrm{m}^{-1}$. Resistant isolates had growth greater than $40 \%$ of the nonamended control at both 1.0 and $100 \mu \mathrm{g} \mathrm{ml} \mathrm{m}^{-1}$. Fifty percent effective concentration $\left(\mathrm{EC}_{50}\right)$ values were calculated for each isolate using linear regression of the percent growth of each isolate compared with the nonamended control plotted against the $\log _{10}$ of the metalaxyl concentration using the Statistical Analysis System (SAS Institute, Inc., Cary, NC). Chi-square analysis was conducted to test the effect of fungicide usage history on the number of isolates in the sensitivity classes.

Allozyme analysis. Mycelium for allozyme analysis was prepared by placing agar disks $(5 \mathrm{~mm})$ of each isolate in petri dishes containing 10 to $20 \mathrm{ml}$ of pea broth (34). The mycelium was removed from the broth after 14 days at $18^{\circ} \mathrm{C}$ and placed in $1.5-\mathrm{ml}$ microcentrifuge tubes. The mycelium was centrifuged at $12,000 \mathrm{rpm}$, and excess water was removed from the top of each sample. Fifty microliters of extraction buffer (20\% sucrose, $2 \%$ Triton-X, $0.01 \%$ bromophenol blue, and $9.8 \mathrm{ml}$ of $\mathrm{H}_{2} \mathrm{O}$ ) and $10 \mathrm{mg}$ of glass beads were added to each microcentrifuge tube, and the mycelium was ground for $30 \mathrm{~s}$ with a hand drill equipped with a separate, sterile pestle for each isolate. Samples were centrifuged for $3 \mathrm{~min}$ at 
$12,000 \mathrm{rpm}$, and the supernatant was collected for allozyme analysis.

Allozyme genotypes were determined on all isolates at the Gpi and Pep loci by polyacrylamide gel electrophoresis (Phastsystem; Pharmacia Biotechnology Inc., Piscataway, NJ). Precast homogeneous polyacrylamide gels $(12.5 \%)$ and standard native buffer strips were used for the Gpi assay, while homogeneous polyacrylamide gels $(12.5 \%)$ with agarose buffer strips made with Triscitrate buffer $(\mathrm{pH} 7.0)$ were used for the $P e p$ assay. The agarose buffer strips were prepared with 3\% agarose using buffer strip molds purchased from Pharmacia.

A $0.3-\mu$ droplet of the supernatant from each homogenized isolate was loaded into a lane of the gel using the sample applicator (Pharmacia Biotechnology Inc.). Gels for the Gpi analysis were run at $300 \mathrm{~V}$ and those for Pep were run at $200 \mathrm{~V}$. Running time for the gels was approximately $45 \mathrm{~min}$ or until the blue dye of the extraction buffer migrated to the end of the gel. Gels were then removed from the gel apparatus, placed in petri dishes, and stained using agar underlay stains (18).

Known isolates of the four clonal genotypes US-1, US-6, US-7, and US-8 were used as standards on each gel. Migration distances of protein from the unknown isolates were compared with migration distances of proteins from the known genotypes. Alleles in individual isolates were scored based on the migration of their proteins relative to the protein produced at the 100 allele, which is the most commonly occurring enzyme species (18).

\section{RESULTS}

One of the eighty-five isolates of $P$. infestans collected was the A1 mating type, and the remaining isolates were the A2 mating type. The A1 isolate was collected in 1994 from a commercial potato field in eastern North Carolina. Three known dilocus genotypes, US-1, US-7, and US-8, and one dilocus genotype not previously reported elsewhere were identified (Table 2). Four allozyme genotypes were identified among the 85 isolates. One isolate was Gpi $86 / 100$, Pep 92/100 and was designated as the US1 genotype. Fifty-five isolates were $G p i$
100/111, Pep 100/100 and were designated as the US-7 genotype. Twenty-four isolates were Gpi 100/111/122, Pep 100/100 and were designated as the US-8 genotype. Five isolates were Gpi 100/100, Pep 92/100 and were designated as the US-18 genotype (Table 2). The unique genotype, US18 , had the same allozyme genotype as the previously described US-6 genotype; however, these isolates were the A2 mating type and were either sensitive or intermediate in response to metalaxyl (Table 2). Typical US-6 genotypes are the A1 mating type (19). The US-18 genotype was collected from tomato plants in 1994 and 1995 and was also collected from tomato in 1996 (11 isolates), 1997 (5 isolates), and 1998 (3 isolates) (data not shown). We are currently conducting DNA fingerprinting analyses on all of the isolates of the US-18 genotype to more fully describe them (19). The isolates are available from our collection for others to evaluate and will be deposited with the American Type Culture Collection.

Seventy-one percent of the isolates of $P$. infestans collected between 1993 and 1995 were resistant to metalaxyl. Six isolates were sensitive, nineteen isolates were intermediate, and sixty isolates were resistant to metalaxyl (Table 2). Although most of the isolates were resistant to metalaxyl, variation among genotypes of $P$. infestans for sensitivity to the fungicide was identified. Metalaxyl-sensitive isolates were found among US-1, US-7, and the new US-18 genotype (Table 2). In fact, no metalaxylresistant isolates were found among the five isolates of the new US-18 genotype. Overall, $\mathrm{EC}_{50}$ values ranged from 0.02 to $1,630 \mu \mathrm{g} \mathrm{ml}^{-1}$. The mean $\mathrm{EC}_{50}$ value for sensitive isolates was $0.30 \mu \mathrm{g} \mathrm{ml}^{-1}$; whereas the mean $\mathrm{EC}_{50}$ value for intermediate isolates was $9.62 \mu \mathrm{g} \mathrm{ml}^{-1}$, and the mean $\mathrm{EC}_{50}$ value for resistant isolates was $123 \mu \mathrm{g} \mathrm{ml}^{-1}$ (Table 2).

Seventeen of the twenty-four isolates (71\%) from fields where no fungicides had been applied were resistant to metalaxyl, and these isolates had the lowest range of $\mathrm{EC}_{50}$ values (0.05 to $216 \mu \mathrm{g} \mathrm{ml}^{-1}$ ) (Table 3). Thirty-one isolates came from fields where only protectant fungicides had been applied. Twenty of the thirty-one isolates $(66 \%)$ were also resistant to metalaxyl, and $\mathrm{EC}_{50}$ values ranged from 0.02 to $506 \mu \mathrm{g} \mathrm{ml}^{-1}$ (Table 3). The greatest number of isolates that were resistant to metalaxyl occurred in fields where metalaxyl had been used (Table 3). Chi-square analysis indicated that there were no statistical differences between fungicide use history and the number of isolates in each sensitivity class. However, the range of $\mathrm{EC}_{50}$ values was greatest ( 0.15 to $1,630 \mu \mathrm{g} \mathrm{ml}^{-1}$ ) among isolates from fields where metalaxyl was used, and isolates

Table 3. Range of $\mathrm{EC}_{50}$ values and metalaxyl sensitivity of isolates of Phytophthora infestans collected from nontreated, protectant-treated, or metalaxyl- and protectant-treated fields in North Carolina, South Carolina, and Tennessee from 1993 to 1995

\begin{tabular}{lccccc}
\hline & \multirow{2}{*}{ EC $_{\mathbf{5 0}}$ range $^{\mathbf{b}}$} & \multicolumn{4}{c}{ No. of isolates } \\
\cline { 3 - 6 } Prior fungicide usage $^{\mathbf{b}}$ & $\left(\boldsymbol{\mu \mathbf { g ~ m l } ^ { \mathbf { 1 } } )}\right.$ & Sensitive & Intermediate & Resistant & Total \\
\hline None & $0.05-216$ & 2 & 5 & 17 & 24 \\
Protectants only & $0.02-506$ & 3 & 8 & 20 & 31 \\
Metalaxyl and protectants $^{c}$ & $0.15-1,630$ & 1 & 6 & 23 & 30 \\
Total $^{c}$ & & 6 & 19 & 60 & 85 \\
\hline
\end{tabular}

${ }^{a}$ Isolates collected from fields or home gardens that were not treated with fungicides or from commercial fields that were treated with protectants or metalaxyl plus protectants.

${ }^{\mathrm{b}}$ Metalaxyl sensitivity and $\mathrm{EC}_{50}$ determined by plating on agar media amended with $0,0.1,1.0,10$, 100 , and $1,000 \mu \mathrm{g}$ of metalaxyl per ml. Sensitive isolates $=<40 \%$ growth at $1.0 \mu \mathrm{g}$ of metalaxyl per $\mathrm{ml}$. Intermediate isolates $=>40 \%$ growth at $1.0 \mu \mathrm{g}$ of metalaxyl per ml and $<40 \%$ growth at $100 \mu \mathrm{g}$ of metalaxyl per ml. Resistant isolates $=>40 \%$ growth at 1.0 and $100 \mu \mathrm{g}$ of metalaxyl per ml.

${ }^{c}$ A chi-square $\left(\chi^{2}\right)$ test was performed and $\chi^{2}=1.519$. The tabular value of $\chi^{2}=9.49$ for 4 degrees of freedom at $P>0.05$. Therefore, fungicide usage did not affect the number of isolates within a sensitivity class.

Table 2. Genotype, mating type, allozyme genotype, metalaxyl sensitivity, $\mathrm{EC}_{50}$ range, and host distribution for isolates of Phytophthora infestans collected from potato and tomato plants in North Carolina, South Carolina, and Tennessee from 1993 to 1995

\begin{tabular}{|c|c|c|c|c|c|c|c|c|c|c|}
\hline \multirow[b]{2}{*}{ Genotype $^{a}$} & \multirow{2}{*}{$\begin{array}{l}\text { Mating } \\
\text { type }\end{array}$} & \multicolumn{2}{|c|}{ Allozyme genotype } & \multicolumn{3}{|c|}{ No. of isolates ${ }^{b}$} & \multirow{2}{*}{$\begin{array}{c}\mathbf{E C}_{50} \text { range }^{\mathrm{b}} \\
\left(\mu \mathrm{g} \mathrm{m} \mathbf{l}^{-1}\right) \\
\end{array}$} & \multicolumn{3}{|c|}{ No. of isolates } \\
\hline & & Gpi & Pep & Sensitive & Intermediate & Resistant & & Potato & Tomato & Total \\
\hline US-1 & A1 & $86 / 100$ & $92 / 100$ & 1 & 0 & 0 & 0.02 & 1 & 0 & 1 \\
\hline US-7 & A2 & $100 / 111$ & $100 / 100$ & 2 & 8 & 45 & $0.23-1,630$ & 2 & 53 & 55 \\
\hline US-8 & A2 & $100 / 111 / 122$ & $100 / 100$ & 0 & 9 & 15 & $0.15-216$ & 9 & 15 & 24 \\
\hline US-18 & A2 & $100 / 100$ & $92 / 100$ & 3 & 2 & 0 & $0.05-3.3$ & 0 & 5 & 5 \\
\hline Total & & & & 6 & 19 & 60 & & 12 & 73 & 85 \\
\hline Mean $\mathrm{EC}_{50}\left(\mu \mathrm{g} \mathrm{ml}^{-1}\right)$ & & & & 0.30 & 9.62 & 123 & & & & \\
\hline
\end{tabular}

a Genotypes identified by mating type and allozyme analysis at glucose-6-phosphate isomerase (Gpi) and peptidase (Pep) loci.

${ }^{\mathrm{b}}$ Metalaxyl sensitivity and $\mathrm{EC}_{50}$ determined by plating on agar media amended with $0,0.1,1.0,10$, 100, and 1,000 $\mu \mathrm{g}$ of metalaxyl per ml. Sensitive isolates $=<40 \%$ growth at $1.0 \mu \mathrm{g}$ of metalaxyl per ml. Intermediate isolates $=>40 \%$ growth at $1.0 \mu \mathrm{g}$ of metalaxyl per ml and $<40 \%$ growth at $100 \mu \mathrm{g}$ of metalaxyl per ml. Resistant isolates $=>40 \%$ growth at 1.0 and $100 \mu \mathrm{g}$ of metalaxyl per ml. 
with the highest $\mathrm{EC}_{50}$ values were found in metalaxyl-treated fields (Table 3 ).

The frequency and distribution of the four dilocus genotypes collected in this study varied between crop (Table 2). The single isolate classified as the US-1 genotype came from a commercial potato field in Camden County in eastern North Carolina in 1994 and showed the greatest sensitivity to metalaxyl $\left(\mathrm{EC}_{50}=0.02 \mu \mathrm{g} \mathrm{ml}^{-1}\right)$ (Table 2). All isolates of the US-18 genotype were found on tomato. Two of the five isolates designated as US-18 came from a commercial tomato field in eastern Tennessee in 1994, and three came from tomato in western North Carolina in 1995. Fifty-five of the isolates were the US-7 genotype, and all but two of these isolates came from tomato. Also, all isolates from commercial tomato fields in coastal South Carolina were the US-7 genotype. Isolates of the US-7 genotype were collected from tomato in each of the 3 years of the study and were the most common genotype found on tomato during that time period. Among the US-8 genotypes, 15 isolates were collected from tomato in western North Carolina in 1994 and 1995, and nine isolates were collected from potato in eastern North Carolina. There were geographical differences in the genotypes found on potato in different regions of the state. All isolates collected from potato in eastern North Carolina were the US-8 genotype, while the two isolates collected from potato in western North Carolina were the US-7 genotype (Fig. 1). No US-7 genotypes were found on potato in eastern North Carolina.

\section{DISCUSSION}

Significant variation was identified among tomato isolates of $P$. infestans from North Carolina for both metalaxyl sensitivity and allozyme genotype. However, little variation in mating type was observed among isolates. All isolates except one were the A2 mating type. Prior to migration events in the latter part of the $1980 \mathrm{~s}$, isolates of $P$. infestans from North Carolina were probably the US-1 genotype, which is characteristically metalaxyl sensitive and the A1 mating type (15). One isolate of $P$. infestans collected in a North Carolina field in 1985 was the A1 mating type, sensitive to metalaxyl, and the US-1.4 genotype (15). In 1992, 12 isolates collected from two tomato fields in North Carolina were identified as the US-7 genotype, the A2 mating type, and metalaxyl resistant (20, 21). Two additional isolates from North Carolina tomatoes were tested by Deahl et al. (6) and found to be resistant to metalaxyl and the A2 mating type. Our data and the work of others suggest that displacement of the US-1, metalaxyl-sensitive genotype by the more aggressive US-7 genotype occurred in North Carolina tomato fields. Furthermore, a change in the diversity of genotypes and a shift to metalaxyl resistance has clearly occurred over the past
7 years in populations of the pathogen on tomato in North Carolina. Previous studies of $P$. infestans by others included a limited number of samples of the pathogen from a few fields in North Carolina and did not extensively test populations from both potato and tomato $(6,15,19-21)$. Our current study included isolates from 33 tomato fields and 8 potato fields within the state and neighboring counties in Tennessee and coastal South Carolina. During this study, three previously reported genotypes and one novel genotype of $P$. infestans were found.

Sixty of the eighty-five isolates collected in this study were resistant to metalaxyl at concentrations greater than $100 \mu \mathrm{g} \mathrm{m} \mathrm{m}^{-1}$. Metalaxyl has not been recommended for control of late blight in potato and tomato production in North Carolina and most of the grower fields sampled in our study did not use the fungicide. Commercial tomato producers maintain a preventative fungicide spray schedule using protectant fungicides such as chlorothalonil and mancozeb every 5 to 7 days to control both early blight and late blight (35). It is interesting that the range of sensitivity to metalaxyl and the corresponding $\mathrm{EC}_{50}$ values were largest in the metalaxyl-sprayed fields. Thus, selection for greater resistance to the fungicide may be occurring in these fields as has occurred elsewhere $(4,21)$. However, the frequency of metalaxyl-resistant isolates was not significantly greater in metalaxyl-sprayed than in unsprayed fields. Others have shown that the use of the fungicide metalaxyl can select for individuals in a population with reduced sensitivity to the fungicide $(3,4,9)$. Many of the isolates from unsprayed fields were from home gardens. Surprisingly, $71 \%$ of the isolates collected from unsprayed home gardens were resistant to metalaxyl. These data suggest that migration of resistant isolates into the unsprayed fields has occurred as has been reported previously (21).

Variation in metalaxyl sensitivity within genotypes was observed. The majority of the isolates with the US-7 and US-8 allozyme genotypes were resistant to metalaxyl, but there were exceptions. For example, eight US-7 isolates were intermediate in sensitivity to metalaxyl and two isolates were sensitive to the fungicide. Similarly, nine US-8 isolates were intermediate in sensitivity to metalaxyl. This is in contrast to studies that demonstrate an almost complete correlation of isolate genotype with metalaxyl sensitivity $(18,21)$. Our findings demonstrate that allozyme genotyping may not be a useful predictor of metalaxyl sensitivity. DNA markers linked to metalaxyl resistance loci have been recently reported for $P$. infestans (12). Different loci were associated with metalaxyl resistance in Mexican and Dutch isolates than in British isolates. In some cases, a semidominant locus is responsible for metalaxyl resistance, but presence of this locus varies between popu- lations from different regions of the world (12). It is likely that development of metalaxyl resistance in $P$. infestans may have arisen independently in different areas, and continued studies need to be conducted to identify markers associated with metalaxyl resistance in U.S. populations. Ultimately, markers more closely linked to metalaxyl resistance genes will provide the best predictors of resistance in populations.

Hot, dry spring temperatures in eastern potato production areas in North Carolina generally prevent late blight from being a problem for potato growers. Many potato growers have not previously applied fungicides for control of late blight, and prior to 1993, late blight epidemics in this area were uncommon. A single US-1 genotype was found in our limited sample of potato isolates. Further sampling in the same field in subsequent years has not identified this genotype. Historical weather data indicate that mean winter temperatures of $6.3^{\circ} \mathrm{C}$ in eastern North Carolina provide the possibility for overwintering of $P$. infestans in infected potato tubers or debris. However, it seems more likely that the pathogen may be introduced annually with the importation of seed potatoes. Tuber blight was found in an eastern North Carolina potato field for the first time in 1997 (T. Wangsomboondee, M. Cubeta, C. T. Groves, and J. B. Ristaino, unpublished data). Most of the isolates from potato were the US- 8 genotype. Other studies in the United States have also identified the US-8 genotype in high frequency among isolates of the pathogen from potato $(3,28)$. Since seed potatoes are shipped into North Carolina and both the US-1 and US- 8 genotypes have been found in the seed-producing regions of the Maine and Canada, it is likely that infected seed potatoes initiate epidemics in eastern North Carolina (20). We have developed a sensitive PCR method for detection of the late blight pathogen in leaves, seed tubers, and fruit of potato and tomato (45). We are currently using PCR and a $P$. infestans specific primer (PINF) to detect the pathogen in infected seed tubers and to optimize sampling strategies $(45,47)$. The PCR detection method needs to be deployed by seed certification agencies to reduce introductions of $P$. infestans into North Carolina and elsewhere.

In western North Carolina, below-freezing winter temperatures may prevent the overwintering of $P$. infestans in crop debris. Most tomato growers in the state produce their own transplants, but the importation of the fungus into North Carolina via movement of transplants from home garden centers is a possibility. Extensive tomato production in Florida during winter may provide a potential route for $P$. infestans to migrate up the east coast. Concurrent with the identification of isolates with the US-7 genotype in North Carolina and Tennessee, others have identified isolates from Florida having US-1, US-6, and US-7 genotypes (20). There is also the possibility that $P$. infestans 
could be transported in tomato fruits or seeds from other tomato-producing areas (46). $P$. infestans can survive in seeds for many months, and tomato repackers import tomato fruit into North Carolina during months when fields are not in production.

Although only a limited number of isolates were collected from potato, most of these isolates were the US-8 genotype and found in eastern North Carolina. We have collected more extensively from potato fields as epidemics have occurred more frequently in recent years, and our data indicate that the US-8 genotype is common. Only two US-7 isolates were found on potato and both were present in western North Carolina where potato production fields occur near tomato production fields and where the US-7 genotype was common on tomato. US-7 isolates are considered tomato aggressive, while US- 8 isolates are considered tomato nonaggressive (25). Approximately $20 \%$ of the isolates collected from tomato in western North Carolina were the US-8 genotype in our study. We did not screen any of our isolates for fitness traits on tomato or potato to compare aggressiveness between isolates of different genotypes. Others have reported that the US-7 genotype is tomato aggressive and our data support this contention, since it was the most commonly found genotype on tomato in our study (25). However, our data indicate that the US- 8 genotype is present on tomato in western North Carolina.

Five isolates from different tomato fields were A2 mating type, Gpi 100/100, Pep $92 / 100$, and sensitive or intermediate in their response to metalaxyl. These isolates were identified in consecutive years from different locations. This genotype, designated here as US-18, was also found in 11 samples from tomato fields in 1996, 5 samples in 1997, and 3 samples in 1998 (T. Wangsomboondee, M. Cubeta, C. T. Groves, and J. B. Ristaino, unpublished data). Introduction of this genotype from other locations in the United States is possible, but at present it has not been reported from other tomato production areas (19) (W. Fry and G. Forbes, personal communication). The US-15 genotype has a similar allozyme genotype and is the A2 mating type; but metalaxyl sensitivity and RFLP fingerprint analysis were not included in previously published work with the US-15 genotype to definitively place our novel isolates in this genotype (19). We have designated our isolates as US-18 to indicate a new genotype. Although, this new genotype may have developed from a sexual recombination event, direct evidence to support this hypothesis is lacking. We have not yet examined tissue directly for evidence of oospores in the field to address this question. We have only found the A2 mating type in these growing regions at the present time.

A second possibility, which merits further research, is the possibility that US-18 developed as a result of a mating type switch from a US-6 isolate. The difficulty with this hypothesis is that the US- 6 genotype has not been found in North Carolina. However, the US-6 genotype is considered tomato aggressive and has been reported on tomato in Florida and elsewhere (20, 26). More extensive sampling and DNA fingerprinting with the RG57 probe and other molecular markers are in progress to provide more definitive evidence to support or refute these hypotheses. It is promising that the US-18 genotype is more sensitive to metalaxyl than the US-7 and US-8 genotypes previously reported (19). US-18 was first isolated in eastern Tennessee in 1994 and has subsequently been found each year in North Carolina since 1995. Since this genotype has now been found for five consecutive seasons, it may be surviving in North Carolina fields. Further work on the overwintering potential of this genotype is needed.

Management of late blight in North Carolina will continue to rely on integrated approaches. Management techniques include detection of the pathogen by the use of PCR methods, the use of pathogen-free seed potato tubers and tomato transplants, elimination of overwintering inoculum such as volunteer plants and cull piles, use of resistant cultivars when available, and judicious use of fungicides $(23,35,38,45,47)$. Knowledge of the changing genetic structure of $P$. infestans populations within our state on both potato and tomato will facilitate management of this devastating disease.

\section{ACKNOWLEDGMENTS}

D. Fraser thanks W. Fry and members of his laboratory at Cornell University for the opportunity to visit his lab and learn techniques that were used in this research. We thank B. Christ of Pennsylvania State University for supplying the US-1 and US-8 isolates of Phytophthora infestans. We thank G. Forbes for sharing the worldwide database of $P$. infestans isolates. We also thank G. Parra and M. Madritch for technical help with some of the experiments and E. Davis and Sarah Goodwin for help with the Phastsystem.

\section{LITERATURE CITED}

1. Caten, C. E., and Jinks, J. L. 1968. Spontaneous variability of single isolates of Phytophthora infestans. 1. Cultural variation. Can. J. Bot. 46:329-348.

2. Chang, T., and Ko, W. 1990. Effect of metalaxyl on mating type of $P$. infestans and P. parasitica. Ann. Phytopathol. Soc. Jpn. 56: 194-198.

3. Chycoski, C. I., and Punja, Z. K. 1996. Characteristics of populations of Phytophthora infestans from potato in British Columbia and other regions of Canada during 1993 to 1995. Plant Dis. 80:579-589.

4. Daggett, S. S., Götz, E., and Therrien, C. D. 1993. Phenotypic changes in populations of Phytophthora infestans from eastern Germany. Phytopathology 83:319-323.

5. Davidse, L. C., Looyen, D., Turkensteen, L. J., and van der Wal, D. 1981. Occurrence of metalaxyl-resistant strains of Phytophthora infestans in Dutch potato fields. Neth. J. Plant Pathol. 87:65-68.

6. Deahl, K. L., DeMuth, S. P., Linden, S. L., and Rivera-Pena, A. 1995. Identification of mating types and metalaxyl resistance in
North American populations of Phytophthora infestans. Am. Potato J. 72:35-49.

7. Deahl, K. L., Goth, R. W., Young, R., Sinden, S. L., and Gallegly, M. E. 1991. Occurrence of the A2 mating type of Phytophthora infestans in potato fields in the United States and Canada. Am. Potato J. 68:717-726.

8. Deahl, K. L., Inglis, D. A., and DeMuth, S. P. 1993. Testing for resistance to metalaxyl in Phytophthora infestans from northwestern Washington. Am. Potato J. 70:779-795.

9. Dowley, L. J., and O'Sullivan, E. 1981 Metalaxyl-resistant strains of Phytophthora infestans (Mont.) de Bary in Ireland. Potato Res. 24:417-421.

10. Drenth, A., Tas, I. C. Q., and Govers, F. 1994 DNA fingerprinting uncovers a new sexually reproducing population of Phytophthora infestans in the Netherlands. Eur. J. Plant Pathol. 100:97-101.

11. Drenth, A., Turkensteen, L. J., and Govers, F. 1993. The occurrence of the A2 mating type of Phytophthora infestans in the Netherlands; Significance and consequences. Neth. J. Plant Pathol. 99:57-67.

12. Fabritius, A.-L., Shattock, R. C., and Judelson, H. S. 1997. Genetic analysis of metalaxyl insensitivity loci in Phytophthora infestans using linked DNA markers. Phytopathology 87:1034-1040.

13. Fry, W. E., Goodwin, S. B., Dyer, A. T. Matuszak, J. M., Drenth, A., Tooley, P. W., Sujkowski, L. S., Koh, Y. J., Cohen, B. A., Spielman, L. J., Deahl, K. L., Inglis, D. A., and Sandlan, K. P. 1993. Historical and recent migrations of Phytophthora infestans: Chronology, pathways, and implications. Plant Dis. 77:653-661.

14. Fry, W. E., Goodwin, S. B., Matuszak, J. M., Spielman, L. J., Milgroom, M. G., and Drenth, A. 1992. Population genetics and intercontinental migrations of Phytophthora infestans. Annu. Rev. Phytopathol. 30:107-129.

15. Goodwin, S. B., Cohen, B. A., Deahl, K. L., and Fry, W. E. 1994. Migration from northern Mexico as the probable cause of recent genetic changes in populations of Phytophthora infestans in the United States and Canada. Phytopathology 84:553-558.

16. Goodwin, S. B., Cohen, B. A., and Fry, W. E. 1994. Panglobal distribution of a single clonal lineage of the Irish potato famine fungus. Proc. Natl. Acad. Sci. U.S.A. 91:11591-11595.

17. Goodwin, S. B., Drenth, A., and Fry, W. E. 1992. Cloning and genetic analyses of two highly polymorphic, moderately repetitive nuclear DNAs from Phytophthora infestans. Curr. Genet. 22:107-115.

18. Goodwin, S. B., Schneider, R. E., and Fry, W. E. 1995. Use of cellulose-acetate electrophoresis for rapid identification of allozyme genotypes of Phytophthora infestans. Plant Dis. 79:1181-1185.

19. Goodwin, S. B., Smart, C. D., Sandrock, R. W., Deahl, K. L., Punja, Z. K., and Fry, W. E. 1998. Genetic change within populations of Phytophthora infestans in the United States and Canada during 1994 to 1996: Role of migration and recombination. Phytopathology 88:939-949.

20. Goodwin, S. B., Sujkowski, L. S., Dyer, A. T. Fry, B. A., and Fry, W. E. 1995. Direct detection of gene flow and probable sexual reproduction of Phytophthora infestans in northern North America. Phytopathology 85:473-479.

21. Goodwin, S. B., Sujkowski, L. S., and Fry, W. E. 1996. Widespread distribution and probable origin of resistance to metalaxyl in clonal genotypes of Phytophthora infestans in the United States and western Canada. Phytopathology 86:793-800.

22. Hohl, H. R., and Iselin, K. 1984. Strains of Phytophthora infestans from Switzerland with 
A2 mating type behaviour. Trans. Br. Mycol. Soc. 83:529-530

23. Hooker, W. J. 1981. Compendium of Potato Diseases. The American Phytopathological Society, St. Paul, MN.

24. Koh, Y. J., Goodwin, S. B., Dyer, A. T., Cohen, B. A., Ogoshi, A., Sato, N., and Fry, W. E. 1994. Migrations and displacements of Phytophthora infestans populations in east Asian countries. Phytopathology 84:922-927.

25. Legard, D. E., Lee, T. Y., and Fry, W. E. 1995. Pathogenic specialization in Phytophthora infestans: Aggressiveness on tomato. Phytopathology 85:1356-1361.

26. Malcolmson, J. F. 1985. Phytophthora infestans A2 compatibility type recorded in Great Britain. Trans. Br. Mycol. Soc. 85:531.

27. Matuszak, J. M., Fernandez-Elquezabal, J., Gu, W. K., Villarreal-Gonzalez, M., and Fry, W. E. 1994. Sensitivity of Phytophthora infestans populations to metalaxyl in Mexico: Distribution and dynamics. Plant Dis. 78:911916.

28. Miller, J. S., Hamm, P. B., and Johnson, D. A. 1997. Characterization of the Phytophthora infestans population in the Columbia Basin of Oregon and Washington from 1992 to 1995. Phytopathology 87:656-660.

29. Mosa, A. A., Kato, M., Sato, N., Kobayashi, K., and Ogoshi, A. 1989. Occurrence of the A2 mating type of Phytophthora infestans on potato in Japan. Ann. Phytopathol. Soc. Jpn. 55:615-620.

30. Neiderhauser, J. S. 1991. Phytophthora infestans-The Mexican connection. Pages 2445 in: Phytophthora. Symposium of the British Mycological Society, the British Society of Plant Pathologists, and the Society of Irish Plant Pathologists. J. A. Lucas, R. C. Shattock,
D. S. Shaw, and L. R. Cooke, eds. Cambridge University Press, Cambridge, England.

31. Neiderhauser, J. S., and Cobb, W. C. 1959. The late blight of potatoes. Sci. Am. 200:100112.

32. Ristaino, J. B. 1998. The importance of archival and herbarium materials in understanding the role of oospores in late blight epidemics of the past. Phytopathology 88:1120-1130.

33. Shattock, R. C. 1988. Studies on the inheritance of resistance to metalaxyl in Phytophthora infestans. Plant Pathol. 37:4-11.

34. Shattock, R. C., Shaw, D. S., Fyfe, A. M. Dunn, J. R., Loney, K. H., and Shattock, J. A. 1990. Phenotypes of Phytophthora infestans collected in England and Wales from 1985 to 1988 . Mating type, response to metalaxyl and isoenzyme analysis. Plant Pathol. 39:242-248.

35. Shoemaker, P. B., Walgenbach, J. F., and Monks, D. W. 1997. 1997 Staked Tomato Pest Control Guide. N.C. Coop. Ext. Serv. Publ. AG-405S. North Carolina State University, Raleigh.

36. Singh, B. P., Roy, S., and Bhattacharyya, S. K. 1994. Occurrence of the A2 mating type of Phytophthora infestans in India. Potato Res. 37:227-231.

37. Spielman, L. J., Drenth, A., Davidse, L. C., Sujkowski, L. J., Tooley, P. W., and Fry, W. E. 1991. A second world-wide migration and population displacement of Phytophthora infestans? Plant Pathol. 40:422-430.

38. Stevenson, W. R. 1993. Management of early and late blight. Pages 141-147 in: Potato Health Management. R. C. Rowe, ed. The American Phytopathological Society, St. Paul, MN

39. Sujkowski, L. S., Fry, B. A., Power, R. J., Goodwin, S. B., Peever, T. L., Hamlen, R. A., and Fry, W. E. 1995. Sensitivities of Mexican isolates of Phytophthora infestans to chlorothalonil, cymoxanil, and metalaxyl. Plant Dis. 79:1117-1120.

40. Sujkowski, L. S., Goodwin, S. B., Dyer, A. T., and Fry, W. E. 1994. Increased genotypic diversity via migration and possible occurrence of sexual reproduction of Phytophthora in festans in Poland. Phytopathology 84:201-207.

41. Tantius, P. H., Fyfe, A. M., Shaw, D. S., and Shattock, R. C. 1986 . Occurrence of the A2 mating type and self-fertile isolates of Phy tophthora infestans in England and Wales. Plant Pathol. 35:578-581.

42. Thierren, C. D., Tooley, P. W., Spielman, L. J., Fry, W. E., Ritch, D. L., and Shelley, S. E. 1993. Nuclear DNA content, allozyme phenotypes, and metalaxyl sensitivity of Phy tophthora infestans from Japan. Mycol. Res. 97:945-950.

43. Tooley, P. W., Fry, W. E., and VillarrealGonzalez, M. J. 1985. Isozyme characterization of sexual and asexual Phytophthora infestans populations. J. Hered. 76:431-435.

44. Trout, C. L., and Ristaino, J. B. 1997. Fungicides affect mating behavior in Phytophthora infestans. Phytopathology 87:S98.

45. Trout, C. L., Ristaino, J. B., Madritch, M. and Wangsomboondee, T. 1997. Rapid detection of Phytophthora infestans in late blightinfected potato and tomato using PCR. Plant Dis. 81:1042-1048.

46. Vartanian, V. G., and Endo, R. M. 1985. Survival of Phytophthora infestans in seeds extracted from infected tomato fruits. Phytopathology 75:375-378.

47. Wangsomboondee, T., and Ristaino, J. B. 1998. PCR detection of Phytophthora infestans in potato tubers. Phytopathology 88:S95. 